\title{
INDUSTRIALISASI DAN PERDAGANGAN: TANTANGAN INDONESIA DALAM ERA AFTA
}

\author{
Endang Sudaryati \\ Dinas Perkebunan Propinsi Jawa Tengah
}

\begin{abstract}
The target and trend of industrial and trade development in Indonesia, particularly related to overseas trade, is broadly influenced by the various challenges time to time, but mainly is influenced by international market and economy.

Trade liberation which is marked with the establishment of World Trade Organization (WTO), and followed by the establishment of free trade territory such as APEC and NAFTA has created regional economic integrity. While AFTA which aims to create free trade in ASEAN territory through payable reduction will make manufacture sector in ASEAN more efficient and more competitive in the global market.

Though the government and public sectors is loyally commit toward the implementation of AFTA, but in fact it is true to say that some another sectors are not ready yet to implement it. Therefore, in order to supporting this commitment, so industrial and trade sector should compete each other, being more efficient and improving the quality of their product.

According to the statements above, the best way in observing AFTA is to make it as a part of long-time process to go into WTO. It is hoped that AFTA will provide the same opportunity for Indonesia to put its products relatively as other ASEAN members before enter global free trade market.
\end{abstract}

Keywords: industrialization, trade liberation, regional economy, import tariffs, AFTA 


\section{PENDAHULUAN}

\section{Latar Belakang}

Bagi kebanyakan negara berkembang, sektor perdagangan khususnya perdagangan luar negeri memegang peranan penting dalam mendukung perekonomian negara tersebut. Seperti halnya di Indonesia, sektor perdagangan yang berbasis pada industrialisasi memegang peranan kunci karena produk yang dihasilkan diharapkan mampu bersaing dengan produk industri negara lain dalam pasar global. Kemajuan pembangunan di sektor industri maupun perdagangan diharapkan dapat memberikan kontribusi yang berarti bagi kemajuan pembangunan dan pertumbuhan ekonomi Indonesia.

Liberalisasi perdagangan dunia banyak dipandang sebagai hal yang menguntungkan karena hal itu akan memungkinkan konsumer dan perusahaan untuk membeli dari produser yang paling efisien. Lebih jauh teori pertumbuhan modern menyarankan bahwa perdagangan internasional dapat mempercepat pertumbuhan dengan menyediakan akses ke pasar yang lebih besar serta teknologi dan praktek majemen superior (Moreno, 1996).

World Trade Oganization (WTO) yang merupakan refleksi dari liberalisasi perdagangan sejak Perang Dunia II mempunyai tujuan utama yaitu non-diskriminasi dalam perdagangan yang meliputi: 1. Tidak memberikan patner perdagangan lebih baik dari yang lain, 2. Menurunkan penghalang perdagangan (trade barriers) pada titik di mana barang impor diperlakukan sama dengan barang domestik. Prinsip pertama dikenal sebagai "most favored nation" (MFN) atau prioritas negara yang paling disukai dan kedua dikenal sebagai "national treatment" atau barang impor diperlakukan sama dengan barang domestik (Moreno, 1996).

Secara global diskusi dan negosiasi yang berkenaan dengan masalah perdagangan berlangsung melalui WTO, sedangkan secara regional dilakukan melalui area perdagangan skala regional seperti, seperti APEC (Asia Pacific Economic Cooperation) dengan 18 negara anggota termasuk Amerika Serikat, kemudian ada North American Free Trade Agreement (NAFTA) yang terdiri atas Amerika Serikat, Kanada dan Meksiko serta ASEAN Free Trade Area (AFTA). 


\section{Pembatasan Masalah}

Industrialisasi dan perdagangan merupakan faktor-faktor penting yang diharapkan mampu mendukung perekonomian Indonesia terutama melalui produk-produk industri yang memiliki daya kompetitif tinggi pada perdagangan di kawasan ASEAN.

Namun seiring dengan digulirkannya Asean Free Trade Area (AFTA) di tahun 2003 yang kemudian diakselerasikan menjadi tahun 2002, mau tidak mau sektor industri dan perdagangan harus berbenah untuk tetap bisa bertahan di era AFTA ini. Di samping itu, Indonesia juga menghadapi tantangan lain karena posisi pertumbuhan ekonomi nasional saat ini sebagai akibat dari "unpredictable condition" (kondisi yang tidak terduga) dan "unbelievable changes" (perubahan yang sulit dipercaya) dari ekonomi dan pasar internasional. Tulisan ini akan secara singkat membahas bagaimana posisi produk industri Indonesia dalam perdagangan di era AFTA ini.

\section{INDUSTRIALISASI DAN PERDAGANGAN}

Pembangunan sektor industri merupakan satu jalur kegiatan untuk meningkatkan kesejahteraan dalam rangka meningkatkan taraf hidup yang lebih maju dan lebih baik. Dengan kata lain, pembangunan industri merupakan suatu fungsi dari tujuan pokok kesejahteraan rakyat, bukan merupakan kegiatan mandiri untuk sekedar mencapai tujuan fisik saja (Arsyad, 1997).

Pertumbuhan yang relatif cepat pada produktivitas industri memiliki implikasi utama terhadap transformasi struktural ekonomi. Peningkatan pendapatan yang berbasis ekonomi luas dari produktivitas yang lebih tinggi akan mempercepat proses transformasi dari sektor berbasis pertanian ke sektor berbasis industri di mana permintaan terhadap barang dari sektor industri diharapkan lebih besar dari pada sektor pertanian. Lebih lanjut dengan harga yang relatif kompetitif, produksi akan meningkat yang dicerminkan dengan penurunan harga barang industri terhadap barang hasil pertanian (Pack, 1988).

Untuk mengestimasi peranan sektor industri dalam perekonomian suatu negara, maka tolok ukur yang umum digunakan adalah seberapa jauh sumbangan sektor industri terhadap pendapatan domestik bruto (PDB), jumlah tenaga yang diserap di sektor tersebut serta sumbangannya terhadap ekspor barang dan jasa (Arsyad, 1997). 
Sumbangan dari sektor manufaktur terhadap PDB tersebut digunakan oleh United Nations for Industrial Development Oganization (UNIDO) untuk menjelaskan tahapan-tahapan dalam industrialisasi yang berlangsung secara perlahan dan berkesinambungan yaitu:

1) non-industrialisasi dengan nilai tambah kurang dari $10 \%$,2) proses menuju industrialisasi dengan nilai tambah $10-20 \%, 3$ ) semi industrialisasi dengan nilai tambah $20-30 \%, 4)$ industrialisasi penuh dengan nilai tambah lebih dari 30\% (Kamaluddin, 1999).

Secara umum perdagangan yang dilaksanakan oleh suatu negara dapat dikategorikan sebagai perdagangan dalam negeri dan perdagangan luar negeri. Untuk perdagangan luar negeri khususnya untuk mencapai target di sektor Industri dan Perdagangan, pemerintah telah menerbitkan Kepres No. 7 tanggal 14 Januari 1999 tentang insentif yang diberikan kepada perusahaan yang menginvestasikan modal di sektor tertentu yang disebut pioner dalam bentuk pajak pendapatan yang dibebankan pada pemerintah (Departemen Luar Negeri RI, 2000).

Untuk meningkatkan ekspor, pemerintah juga telah memperluas cakupan komoditas yang diberi fasilitas ekspor melalui 'Particular Export Companies Facility' (fasilitas ekspor perusahaan tertentu). Kebijakan di bidang perdagangan luar negeri diarahkan untuk meningkatkan nilai ekspor, diversitas tipe komoditas, kompetitif yang kuat, memperluas akses pasar, mempromosikan komoditas non migas dan menyelesaikan masalah ekspor.

Di sisi lain, kebijakan impor ditujukan untuk mengontrol barang impor untuk keperluan produksi dan konsumsi, keamanan negara dan lingkungan. Kebijakan impor antara lain meliputi pembatasan impor, prosedur perdagangan impor seperti perijinan, kuota, bea impor, penanganan praktek impor yang tidak adil (Department of Foreign Affairs, 2000).

Tabel 1 dan 2 memberikan gambaran tentang perdagangan luar negeri Indonesia melalui aktivitas ekspor dan impor di antara negara anggota ASEAN. 
Tabel 1. Ekspor Negara ASEAN Tahun 1996-2000 (Jutaan dolar AS)

\begin{tabular}{|l|r|r|r|r|r|}
\hline Negara & \multicolumn{1}{|c|}{1996} & \multicolumn{1}{c|}{1997} & \multicolumn{1}{c|}{1998} & \multicolumn{1}{c|}{1999} & \multicolumn{1}{c|}{2000} \\
\hline Brunei Darussalam & 2.593 & 2.656 & 1.889 & 2.537 & 3.362 \\
Kamboja & 644 & 862 & 900 & 980 & 1.223 \\
Indonesia & 50.188 & 56.298 & 50.371 & 51.242 & 62.510 \\
Laos & 321 & 317 & 337 & 302 & 350 \\
Malaysia & 76.859 & 77.390 & 71.823 & 83.933 & 98.099 \\
Myanmar & 930 & 1.011 & 1.113 & 1.138 & 1.375 \\
Filipina & 20.543 & 25.228 & 29.496 & 34.210 & 37.295 \\
Singapura & 126.010 & 125.746 & 110.591 & 115.639 & 138.936 \\
Thailand & 54.667 & 56.725 & 52.878 & 56.800 & 67.942 \\
Vietnam & 7.337 & 9.269 & 9.365 & 11.540 & 14.308 \\
\hline ASEAN & 340.092 & 355.502 & 328.763 & 358.321 & 425.400 \\
\hline
\end{tabular}

Sumber: Asean Secretariat, ASCU data base

Tabel 2. Impor Negara ASEAN tahun 1996-2000 (Jutaan dolar AS)

\begin{tabular}{|l|r|r|r|r|r|}
\hline Negara & \multicolumn{1}{|c|}{1996} & \multicolumn{1}{c|}{1997} & \multicolumn{1}{c|}{1998} & \multicolumn{1}{c|}{1999} & \multicolumn{1}{c|}{2000} \\
\hline Brunei Darussalam & 2.345 & 2.000 & 1.311 & 1.251 & 1.493 \\
Kamboja & 1.072 & 1.092 & 1.073 & 1.212 & 1.468 \\
Indonesia & 44.240 & 46.223 & 31.942 & 30.598 & 37.423 \\
Laos & 690 & 648 & 553 & 554 & 437 \\
Malaysia & 72.850 & 73.738 & 54.174 & 61.161 & 77.173 \\
Myanmar & 1.888 & 2.160 & 2.431 & 2.366 & 2.172 \\
Filipina & 31.885 & 36.355 & 29.524 & 29.252 & 30.380 \\
Singapura & 123.786 & 124.628 & 95.780 & 104.337 & 127.536 \\
Thailand & 70.815 & 61.349 & 40.643 & 47.529 & 62.423 \\
Vietnam & 10.480 & 10.569 & 10.346 & 10.460 & 13.680 \\
\hline ASEAN & 360.051 & 358.762 & 267.777 & 288.720 & 354.185 \\
\hline
\end{tabular}

Sumber: Asean Secretariat, ASCU data base

Dari kedua tabel di atas, terlihat bahwa Indonesia menduduki urutan ke 4 sesudah Singapura, Malaysia dan Thailand untuk kegiatan ekspor dan impor. Untuk kegiatan ekspor dan impor, Indonesia mengalami peningkatan kecuali tahun 1998 dan 1999 untuk kegiatan impor di mana pengaruh krisis ekonomi tampaknya mempengaruhi profil ekspor impor seluruh anggota ASEAN. Data tersebut 
menunjukkan bahwa total ekspor ASEAN tumbuh 19.9\% dari 358.321 juta dolar di tahun 1999 menjadi 425.400 juta dolar di tahun 2000. Sedangkan total impor ASEAN tumbuh $22.8 \%$ dari 288.720 juta dolar menjadi 354.185 juta dolar di tahun 2000 .

\section{ASEAN FREE TRADE AREA (AFTA)}

Asean Free Trade Area (AFTA) secara formal disetujui untuk dibentuk pada Pertemuan puncak ke 4 ( $4^{\text {th }}$ ASEAN Summit $)$ di Singapura oleh para pemimpin negara ASEAN dengan menandatangani Singapore Declaration dan Framework Agreement on Enhancing ASEAN Economic Cooperation. Secara resmi AFTA dibentuk pada tahun 1993 untuk meningkatkan daya kompetitif ASEAN sebagai dasar produksi yang berorientasi pada pasar dunia (Indonesian Business Perspective, 2002).

Negara anggota AFTA memiliki populasi lebih dari 500 juta orang, lebih besar dari pada Uni Eropa dengan populasi 372 juta orang. Total perdagangan AFTA berjumlah 250 miliar dolar, di mana $20 \%$ nya berada di dalam AFTA sendiri (Moreno, 1996).

AFTA berkeinginan untuk menurunkan halangan perdagangan di antara anggotanya. Selain berupaya mengimplementasikan berbagai kebijakan liberalisasi seperti penurunan tarif (bea), AFTA juga mengeliminasi penghalang non-tarif di antara anggota, memfasilitasi perdagangan seperti harmonisasi klasifikasi tarif, standarisasi produk yang saling menguntungkan dan merevisinya untuk memperkuat transparansi serta membentuk kawasan investasi ASEAN yang akan menarik bagi investasi asing secara langsung.

Anggota AFTA memiliki insentif baik ekonomi dan politik untuk mencapai integrasi yang lebih dekat. Namun AFTA juga memiliki insentif yang kuat untuk melakukan liberalisasi perdagangan baik dalam skala kawasan maupun skala global karena perolehannya cukup besar. AFTA juga akan tetap bergantung pada pasar di luarnya seperti Uni Eropa dan APEC untuk mendukung pertumbuhan yang cepat. Selain itu keterbukaan AFTA terhadap pasar di luar juga merupakan jalan terbaik untuk meminimalkan friksi perdagangan (Moreno, 1996).

Pada pertemuan tingkat menteri ekonomi di Hanoi tahun 1998, disepakati untuk mempercepat implementasi AFTA dari tahun 2003 menjadi tahun 2002. Salah satu poin penting dalam AFTA adalah 
penurunan bea impor (import tariffs) yang diatur melalui suatu mekanisme yang disebut 'The Common Effective Preferential Tariff' (CEPT). Melalui mekanisme CEPT ini maka bea dari barang yang diperdagangkan di kawasan ASEAN akan direduksi menjadi 0-5\% pada tahun 2003, dengan catatan tahun 2006 untuk Vietnam dan 2008 untuk Laos dan Myanmar. Dengan mekanisme ini pada tahun 2001, terdapat 42.377 bea impor untuk 5 negara anggota ASEAN, Indonesia, Malaysia, Singapura, Brunei Darussalam, dan Filipina akan direduksi antara 0-5\% yang dimasukkan dalam daftar (list) yang disebut The Inclusion List (Asean Secretariat, 2002).

Di samping The Inclusion List, anggota ASEAN juga memiliki pilihan untuk produk di luar daftar tersebut yang meliputi Temporary list; Sensitive list; dan General Exception list. Temporary list meliputi produk di mana negara tersebut belum siap untuk menurunkan beanya, antara lain plastik, kendaraan, dan kimia yang mencakup sekitar $15 \%$ dari total bea. Sedangkan Sensitive list mencakup sejumlah kecil produk pertanian yang dipertimbangkan sebagai produk 'sensitif seperti beras dan gula di mana implementasinya ditunda hingga tahun 2010. Untuk General List merupakan daftar dari produk negara ASEAN yang disetujui untuk tidak dimasukkan dalam CEPT karena alasan keamanan negara, moral masyarakat, kesehatan, artistik, sejarah maupun nilai arkeologi. Hanya sekitar $1 \%$ saja yang masuk dalam kategori ini (Indonesian Business Perspective, 2002).

Secara rata-rata terjadi penurunan bea dalam The Inclusion List yaitu dari $12.76 \%$ di tahun 1993 saat program reduksi bea dimulai menjadi $6.38 \%$ pada tahun 1997. Dijadwalkan bahwa pada tahun 2003 reduksi bea akan berada pada $2.25 \%$ (Indonesian Business Perspective, 2002).

Tabel 3. Rata-Rata Penurunan Bea CEPT di Antara Negara ASEAN

\begin{tabular}{|l|c|c|c|c|c|c|}
\hline Negara & 1998 & 1999 & 2000 & 2001 & 2002 & 2003 \\
\hline Brunei & 1.35 & 1.29 & 1.00 & 0.97 & 0.94 & 0.87 \\
Indonesia & 7.04 & 5.83 & 4.97 & 4.63 & 4.20 & 3.71 \\
Laos & 5.00 & 5.00 & 5.00 & 5.00 & 5.00 & 5.00 \\
Malaysia & 3.58 & 3.17 & 2.73 & 2.54 & 2.38 & 2.06 \\
Myanmar & 4.47 & 4.45 & 4.38 & 3.32 & 3.31 & 3.19 \\
Philippines & 7.96 & 7.00 & 5.59 & 5.07 & 4.80 & 3.75 \\
Singapore & 0.00 & 0.00 & 0.00 & 0.00 & 0.00 & 0.00
\end{tabular}


Lanjutan Tabel 3 ...

\begin{tabular}{|l|c|c|c|c|c|c|}
\hline Negara & 1998 & 1999 & 2000 & 2001 & 2002 & 2003 \\
\hline Thailand & 10.56 & 9.75 & 7.40 & 7.36 & 6.02 & 4.64 \\
Vietnam & 6.06 & 3.78 & 3.30 & 2.90 & 2.89 & 2.02 \\
\hline ASEAN & 5.37 & 4.77 & 3.87 & 3.63 & 3.25 & 2.68 \\
\hline
\end{tabular}

Sumber: Asean Secretariat, 2002

Meskipun dari tabel di atas terlihat bahwa secara rata-rata ASEAN terjadi tren penurunan bea CEPT, bea yang diprediksi masih belum mencapai $2.25 \%$. Hal ini dikarenakan tidak semua anggota AFTA akan siap mengimplementasikan reduksi tarif secara bersamasama seperti Laos. Berdasarkan tabel tersebut jelas bahwa Indonesia belum dapat memenuhi target $2.25 \%$ tetapi masih dalam kisaran kesepakatan bea CEPT, yaitu antara $0-5 \%$. Jelas ini merupakan tantangan bagi Indonesia apabila ingin bisa kompetitif di antara anggota AFTA.

\section{PEMBAHASAN}

Pada tanggal 1 Januari 2002, negara ASEAN resmi memasuki kawasan perdagangan bebas ASEAN atau AFTA khususnya bagi Indonesia, Malaysia, Thailand, Brunei Darussalam, Singapura dan Filipina. Sedangkan 4 anggota lainnya, yaitu Laos, Myanmar, Kamboja dan Vietnam akan resmi bergabung AFTA antara tahun 2006-2010 (Asean secretariat, 2002).

Apakah makna AFTA bagi Indonesia? Pertama, produk impor dari negara ASEAN akan menjadi lebih tersedia di Indonesia. Skema AFTA mensyaratkan bahwa anggotanya untuk menurunkan bea impor kecuali beberapa produk antara $0-5 \%$, dan ini berarti bahwa orang Indonesia tidak hanya akan memiliki pilihan yang lebih luas akan produk barang tetapi juga dapat memperolehnya pada harga yang lebih murah. Namun di sisi lain subsidi gas dan listrik akan secara perlahan dihilangkan untuk bisa berkompetisi lebih adil dengan negara-negara ASEAN, karena ASEAN tidak dapat menerima kompetisi dari barang yang murah karena subsidi. Tentu saja hal ini akan merupakan masalah bagi Indonesia. Namun di sisi lain produsen Indonesia akan menghadapi pasar bebas yang akan memungkinkan 
mereka untuk berkompetisi pada pasar regional yang mungkin sebelumnya belum tersentuh.

Konsekuensi dari implementasi AFTA adalah sistem ekonomi Indonesia akan makin terintegrasi ke dalam sistem ekonomi ASEAN. Di samping adanya sistem perdagangan menjadi adil di sisi lain persaingan perdagangan akan menjadi semakin keras. Untuk mengantisipasi hal tersebut maka solusinya adalah meningkatkan efisiensi di sektor industri dan perdagangan agar bisa bertahan dalam menghadapi persaingan yang semakin besar. Penghapusan berbagai pungutan yang tidak mempunyai dasar yang jelas serta tidak mendorong daya kompetisi produk dalam perdagangan luar negeri merupakan langkah yang harus ditempuh.

Integrasi ekonomi regional melalui AFTA merupakan langkāh maju dengan potensi keuntungan yang besar bagi perekonomian Indonesia dengan syarat: stabilitas politik dan kemauan ekonomi. AFTA akan menyediakan eliminasi penghalang bea dan non bea yang akan membawa efisiensi yang lebih besar dalam produksi dan kompetisi jangka panjang (Indonesian Business Perpective, 2002). Perdagangan intra-regional dengan diikuti pengurangan penghalang (barrier) akan memberikan konsumer pilihan yang lebih besar pilihan dengan kualitas produk yang lebih baik.

Indonesia sebagai negara anggota ASEAN terbesar harus mendapatkan keuntungan dari persetujuan (agreement) ini. Dalam beberapa tahun terakhir, perdagangan Indonesia dengan negara anggota ASEAN lainnya tumbuh pada tingkat yang relatif tetap dengan rata-rata di atas $12.35 \%$ per tahun (Indonesian Business Perspective, 2002).

Lebih jauh, Indonesia memiliki keuntungan komparatif terhadap negara ASEAN lainnya dengan banyaknya produk yang dihasilkan. Dilaporkan bahwa terdapat 28 tipe produk Indonesia yang memiliki keunggulan komparatif termasuk plywood, aluminium, sepatu, gelas dan baja (Indonesian Business Perpective, 2002). Akan tetapi, untuk bisa memperoleh keuntungan maksimal dari AFTA, Pemerintah Indonesia dan sektor swasta harus memprioritaskan sektor-sektor industri dan perdagangan dengan kompetisi tinggi dan memberikan kebijakan yang mendukung pada sektor tersebut. 
Menurut Simamora (2001), banyak pengusaha lokal kuatir tentang rendahnya daya kompetisi dan efisiensi dari industri lokal daripada rendahnya bea impor selama era AFTA. Mereka mengkuatirkan banyaknya biaya yang dikenakan oleh pemerintah daerah dan praktek tidak terpuji oleh pejabat daerah karena hal ini akan menyebabkan harga produk lokal dan membuat makin sulit untuk berkompetisi dengan produk impor yang lebih murah selama era AFTA.

Banyaknya biaya dan suap yang diminta oleh pejabat daerah yang makin meningkat semenjak otonomi daerah menyebabkan mahalnya biaya produksi di samping mahalnya biaya transportasi. Disebutkan bahwa pada prinsipnya sebagian dari mereka siap menghadapi AFTA selama pemerintah dapat menghilangkan biayabiaya tinggi tersebut.

Industrialisasi merupakan suatu proses transformasi dan perubahan struktural yang berkelanjutan sehingga dalam proses industrialisasi tersebut terdapat tahapan-tahapan yang menunjukkan tingkat perkembangan dari industri, mulai dari yang sederhana hingga yang paling canggih. Tahapan-tahapan tersebut dipercaya berlangsung secara perlahan dan berkesinambungan.

Dalam konteks era AFTA, maka kebijakan perdagangan luar negeri mesti berdasarkan pada penerapan sistem perdagangan yang dinamis dan fleksibel sehingga tidak terpaku pada orientasi keuntungan dan kesejahteraan dalam jangka pendek tetapi juga memaksimalkan hasil industrialisasi untuk jangka panjang. Sesuai sifat dari tahapan dalam industrialisasi maka pemilihan produk yang memiliki keunggulan komparatif tidak dapat didasarkan pada sesaat. Perlu peninjauan yang berulang dan sering jika kondisi-kondisi yang mendasari pemilihan kebijakan itu berubah atau diprediksi akan selalu berubah. Kebijakan pemerintah tentang pembebasan pajak bagi sektor industri pioner yang diatur melalui Kepres No.7/1999 merupakan salah satu langkah bijaksana dalam mendorong ekspor luar negeri. Di samping itu, pemberian fasilitas ekspor melalui Particular export companies facility diharapkan juga dapat meningkatkan ekspor komoditas yang kompetitif di perdagangan global.

Indonesia mengalami masa-masa lebih sulit dibandingkan dengan negara ASEAN lainnya dalam pemulihan ekonomi setelah krisis tahun 1997. Beberapa ahli kuatir tentang waktu implementasi 
AFTA dan kemungkinan dampaknya terhadap sektor swasta. Akan tetapi pemerintah Indonesia dan sektor swasta memiliki komitmen untuk tetap mendukung AFTA, namun juga menyadari banyak sektor bisnis yang belum siap untuk mengimplementasikan perjanjian tersebut. The Chamber of Commerce and Industry (KADIN) menyebutkan bahwa berdasarkan survey yang dilakukan terhadap $\mathbf{8 0}$ asosiasi bisnis terdapat $27 \%$ produk lokal yang belum siap memasuki era AFTA (Simamora, 2001). Namun mau tidak mau, dalam upaya memegang komitmen AFTA tersebut akan sektor industri mesti didorong untuk bersaing dan memperbaiki kualitas barang dan efisiensi.

Pada sisi yang menjanjikan, terdapat beberapa indikasi bahwa beberapa manufaktur terutama produser kendaraan merencanakan memindahkan lokasi produksi ke Indonesia meskipun berlarutlarutnya masalah politik dan hambatan kebijakan ketenagakerjaan. Sebagai contoh, Honda Motor Company telah mengumumkan bahwa mereka berencana untuk menginvestasikan US\$ 30 juta untuk membangun pabrik mobil baru di Jawa Barat untuk jenis Minivan. Juga diperkirakan bahwa Indonesia akan menerima kendaraan impor dari Thailand, Malaysia dan Filipina. Pada bagian ini, Indonesia bisa kompetitif untuk pasar ASEAN (Indonesian Business Perspective, 2002).

Di luar masalah ketidakstabilan dan isu politik, para ahli sependapat bahwa komitmen Indonesia terhadap AFTA adalah merupakan kenyataan bahwa ASEAN secara aktif berusaha untuk memperkuat hubungan ekonomi dengan China, Jepang, Korea, Australia dan New Zealand. Dengan adanya ASEAN-China Free Trade Area yang dijadwalkan menjadi efektif dalam 10 tahun, Indonesia mungkin akan kalah terhadap China kecuali bisa mengupayakan kerjasama. Seperti Indonesia, China juga memiliki biaya tenaga kerja yang murah tetapi memiliki kapasitas teknologi yang lebih baik dan pasar yang tidak terlalu tergantung pada pembiayaan luar negeri.

Satu keuntungan yang dimiliki oleh Indonesia adalah sumber daya alam yang relatif melimpah yang bila ditangani dengan baik dapat menjadi produk dengan keunggulan komparatif karena faktor produksi tersedia cukup dengan biaya relatif murah. Akan tetapi pemilihan teknologi dalam proses industrialisasi juga merupakan faktor yang tidak dapat diabaikan begitu saja. Pemilihan teknologi 
yang tidak tepat dapat menjadi bumerang dalam rangka pembangunan ekonomi. Setiap negara memiliki pertimbangan tersendiri dalam pemilihan teknologi dalam industrialisasi. Namun secara umum pertimbangan berikut lazim digunakan dalam pemilihan teknologi alternatif dalam industrialisasi, yaitu: 1) Nilai tambah yang diperoleh dari teknologi yang dipilih, 2) Pemanfaatan bahan lokal/setempat, 3) Kesempatan kerja yang produktif, 4) Dampak teknologi terhadap neraca pembayaran luar negeri melalui penerimaan devisa atau penghematan dalam penggunaannya.

Tidak kalah penting adalah kegiatan pameran dan promosi terhadap produk industri Indonesia. Melalui pameran perdagangan ini diharapkan dapat mempromosikan produk industri Indonesia sekaligus membuka kesempatan pasar baru dan diharapkan dapat meningkatkan perolehan pasar ekspor Indonesia. Hasil ini dapat direfleksikan dalam bentuk kontrak bisnis, transaksi, permintaan, kerjasama pemasaran dan kerjasama bisnis. Bentuk promosi melalui misi perdagangan dan penanaman modal (Trade and Investment mission) pada negara tujuan ekspor merupakan upaya penting untuk memperbaiki image produk Indonesia di mata dunia internasional.

\section{PENUTUP}

\section{Kesimpulan}

Liberalisasi perdagangan global sebagaimana diatur oleh World Trade Organization akan berdampak pada kemudahan bagi konsumen untuk memperoleh barang dari produsen yang paling efisien. Di samping itu, liberalisasi perdagangan internasional dapat mempercepat pertumbuhan ekonomi melalui akses ke pasar yang lebih besar melalui sistem kompetisi.

Implementasi Asean Free Trade Area (AFTA) sebagai kawasan perdagangan bebas ASEAN akan menjadikan produk impor dari negara ASEAN akan lebih mudah tersedia di Indonesia melalui mekanisme pengurangan bea atau CEPT yang memungkinkan harga produk impor menjadi murah. Di lain pihak, produsen Indonesia akan memiliki akses yang memungkinkan produk mereka menjadi lebih kompetitif pada pasar regional yang sebelumnya belum digarap.

Sebagai komitmen terhadap implementasi AFTA, pemerintah Indonesia dan sektor industri harus berbenah untuk meningkatkan 
efisiensi serta memperbaiki kualitas produk agar bisa berkompetisi dengan produk impor.

Sebagai penutup, cara terbaik untuk melihat AFTA dalam kapasitasnya untuk memperkuat industri dan perdagangan Indonesia adalah sebagai "long term process" (proses jangka panjang) di mana AFTA merupakan media untuk memasuki World Trade Organization (WTO). AFTA memberikan kesempatan bagi Indonesia untuk menempatkan produk-produknya berada pada posisi yang relatif sama dengan produk negara anggota ASEAN sebelum memasuki Global Free Trade market.

\section{Solusi}

Untuk bisa memanfaatkan momentum dari implementasi AFTA, maka pemerintah bersama dengan sektor industri dan perdagangan perlu melakukan langkah-langkah sebagai berikut:

1. Memanfaatkan potensi sumber daya alam dan tenaga kerja yang melimpah.

2. Mengembangkan produk industri yang memiliki keunggulan komparatif.

3. Mengembangkan kebijakan industri dan perdagangan yang mendukung pertumbuhan industri.

4. Menghilangkan pos-pos ekonomi biaya tinggi yang akan menyebabkan produk Indonesia menjadi kurang kompetitif.

\section{DAFTAR PUSTAKA}

Arsyad, L. 1997. Ekonomi Pembangunan. Edisi 3. Yogyakarta: STIE YKPN.

Asean Secretariat. 2002. (Online), (http://www.asean.or.id, tanpa waktu akses)

Department of Foreign Affairs, RI. 2000. An Official Handbook. Indonesian Embassy, Ottawa, Canada.

Indonesian Business Perspective. 2002. AFTA 2002 and Beyond: Opportunities and Challenges for Indonesia. Harvest International's Journal for Decision Makers. February. (Online edition), (tanpa alamat website, tanpa waktu akses) 
2002. Consequences and Challenges. Harvest International's Journal for Decision Makers. February. (Online edition), (tanpa alamat website, tanpa waktu akses).

2002. The CEPT. Harvest International's Journal for Decision Makers. February. (Online edition), (tanpa alamat website, tanpa waktu akses)

Kamaluddin, R. 1999. Pengantar Ekonomi Pembangunan. Jakarta: Lembaga Penerbit Fakultas Ekonomi, Universitas Indonesia.

Moreno, R. 1996. Pacific Basin Notes: Trade Liberalization in the Pacific Basin. FRBSF Economic Letter.

Pack, H. 1988. Industrialization and Trade In: Handbook of Development Economics. Vol. 1. H. Chenery and T.N. Srinivasan (Eds). North Holland: Elsevier Science Publishers.

Simamora, A.P. 2001. Will AFTA or won't AFTA? The Jakarta Post Sunday. January 6, 2001. 